\title{
The Competitive Effects of Parity Clauses on Online Commerce
}

\begin{abstract}
Ariel Ezrachi*
Parity clauses, also known as most-favoured-nation clauses, are designed to address the hold-up problem in vertical relations and facilitate investments and efficiencies by the downstream platform. However, when designed too broadly, they have the potential of undermining the dynamics of competition and reducing consumer welfare. This paper explores the welfare effects of parity clauses and reflects on the level of intervention they may call for. It reviews the possible theories of harm associated with parity clauses and draws a dividing line between the effects generated by narrow and wide parity.
\end{abstract}

Key words: Parity clause, Most Favoured Nation clause, Price Comparison websites

JEL Codes: K21, L11, L16, L41, L42

\section{Introduction}

Operating behind the scenes of online commerce; parity clauses, also known as 'mostfavoured-nation clauses' (MFNs) ${ }^{1}$ have played an increasingly significant role in the relationship between price comparison websites (PCWs) and their suppliers. These clauses, which have become a common feature in recent years, aim to provide assurance to the downstream online platform that it has received goods or services from the supplier, at terms that are at least as favourable as those offered to any other buyers. The rationale behind such restriction lies in the vertical relationship between the PCW and the supplier. It is designed to resolve the hold-up problem, often manifested in vertical relationships, by removing the risk

\footnotetext{
Slaughter and May Professor of Competition Law, The University of Oxford. Director, Oxford University Centre for Competition Law and Policy. The paper was presented at the 2015 OECD Hearing on 'Across Platform Parity Agreements'. I am grateful for comments received from participants at the hearing.

The research, on which this paper is based, was financially supported by Slaughter and May, which acts for Booking.com. The usual disclaimer applies - the views expressed in this paper and any errors or omissions are the author's own.

${ }^{1}$ Also known as 'Most-Favoured-Customer clauses' and, more generally, 'price relationship agreements' (PRAs).
} 
of the supplier, or other sellers, free-riding on the PCWs' investment in promoting the supplier's products and services.

MFNs are commonly divided into two distinct categories: narrow and wide, differentiated by their scope and effects.

A narrow MFN links the price and terms quoted on an online platform, to those available directly on the upstream supplier's website, ensuring that the former will not be less attractive than the latter.

A wide MFN provides for similar protection on a wider scale, aiming to ensure that the price and terms quoted through the platform in question will not be higher than the price available directly on the upstream supplier's website or on any other platform.

In addition to the narrow/wide classification, MFNs may also be categorised by the distribution model that they support.

In a wholesale model, the agreement governs the price at which the upstream supplier will sell to the online platform, but does not determine the final price available on the platform. In such instances, the MFN helps to ensure the platform's competitive cost structure. ${ }^{2}$

Under an agency model, the upstream supplier sets the final price on the platform, and the platform receives a commission for each sale made under an agreed revenue-sharing clause. In these cases, the platform does not purchase the product but rather acts as an agent, selling it on behalf of the supplier. The MFN does not affect the platform's cost structure but ensures that products or services sold through it will be priced competitively. ${ }^{3}$

Other distribution models may include a combination of both wholesale and agency elements. For instance, one may design a hybrid wholesale model (such as the merchant model) which

\footnotetext{
${ }^{2}$ Michael L. Weiner and Craig G. Falls, 'Counselling on MFNs After e-books' (Deschert LLP, 2014) 4 $<$ https://www.dechert.com/Counseling_on_MFNs_After_e-books_05-01-2014/> accessed 2015.

${ }^{3} I d$.
} 
includes a fixed mark-up. Under such model the upstream supplier determines the wholesale price, while the contract between the parties includes an agreed margin for the retailer. ${ }^{4}$

The scope and nature of parity clauses have been the subject of increased scrutiny in recent years, as competition agencies grapple with the task of identifying the dividing line between their possible pro- and anti-competitive effects. The task is not an easy one, as MFNs may generate a mixture of effects, which vary depending on the scope of the clause, the nature of distribution and the characteristics of the relevant market.

This article explores the welfare effects generated by price parity clauses between PCWs and their suppliers. The paper focuses on the use of MFNs in an agency model setting, which (together with the merchant model) is the most common business model utilised by suppliers and PCWs worldwide. It explores the differences between narrow and wide parity clauses the dissimilar competitive effects they generate and subsequently the divergent enforcement approach they call for.

The discussion begins by considering the economic rationale for price parity clauses and the welfare benefits they may generate. It then contrasts these benefits with the welfare harm that parity clauses may trigger. The analysis distinguishes between the different pro- and anticompetitive effects generated by wide and narrow MFNs. Cases discussed include the high profile Apple e-book investigation, Amazon, the $H R S$ decision and the more recent Booking.com commitments. The paper concludes with reflections on the legality of MFN clauses and the level of competition intervention to which they ought to be subjected.

\section{The Economic Rationale}

The environment in which MFNs are typically present consists of an upstream supplier that uses a downstream online platform, such as a PCW, to sell its products. The supplier may use the online platform as its sole channel, or in addition to selling goods through other means (whether offline or online). The online platform, on its part, invests in demand-enhancing features, which may include additional services such as marketing, advertising, after-sales

\footnotetext{
${ }^{4}$ From a competition perspective, hybrid models can be appraised with reference to the de-facto effect they generate. In the example provided, the agreed commission which is added to the wholesale price results in a known retail price and the clause is therefore akin to an agency model.
} 
support, advice and guarantees. These efforts promote the supplier's product and its brand. In addition, they position the online platform as an attractive sales channel. The MFN provides parity provisions which limit the freedom of the upstream supplier when offering its product through other sales channels.

As noted above, the typical model used by many suppliers and online platforms is the agency model, under which the downstream platform provides customers with demand-enhancing features and receives a commission from the upstream supplier for every sale it facilitates. It is important to note the difference between the business model used by PCWs which is at the centre of this paper, and the business model used by online (meta) search engines. The former rely on an agency model and commission per sale to reward them for their demand-enhancing investments. The latter generate their income from advertising and successful referrals to the supplier or PCW. Contrary to PCWs, the search engines are generally remunerated based on the number of clicks which lead to the advertisers' website, irrespective of whether a sale subsequently takes place.

\section{Externalities}

As is the case in many vertical settings, one of the main barriers to a company's successful operation in the downstream market is the risk of free-riding. ${ }^{5}$ One often identifies a vertical externality between the upstream supplier and the downstream retailer, which undermines the retailer's incentive to invest. In an online environment, such an externality may arise when the supplier is able to undercut its price or terms of sales compared to the PCW, thereby incentivising consumers to use the PCW for search, information and other services while subsequently concluding the transaction via the upstream supplier.

In addition, when several PCWs operate downstream, a horizontal externality may emerge, since online platforms may free-ride on one another's investment in promotion and demandenhancing features. This externality may again dis-incentivise an online platform from investing in features which do not tie the user to the platform, such as providing customer

\footnotetext{
${ }^{5}$ Also known as the billboard effect. See, for example: Chris Anderson, 'The Billboard Effect: Online Travel Agent Impact on Non-OTA Reservation Volume' (2009) Cornell Hospitality Reports, 9(16), 6-9 $\langle$ http://scholarship.sha.cornell.edu/chrpubs/2/> accessed 2015; Hans W. Friederiszick and Ela Głowicka 'Competition policy in modern retail markets' (2015) J Antitrust Enforcement <http://antitrust.oxfordjournals.org/content/early/2015/11/26/jaenfo.jnv030.abstract> accessed 6 Jan 2016.
} 
recommendations, instructions, tips, currency conversion, a loyalty program (with special discounted rates), maps, and other information. ${ }^{6}$ These effects subsequently undermine the PCW's incentive to promote and advertise its suppliers' services and products online.

These externalities are particularly noticeable when considering the operation of PCWs in the modern online environment. Users gain information not only through these platforms but also through (meta) search engines, through which they can identify and compare the best price, service and terms, and selectively engage with each of the providers. ${ }^{7}$

\section{The role played by parity clauses}

Parity clauses are often introduced into the vertical relationship in order to minimise externalities and facilitate investment. Consider, for instance, a narrow MFN in which the supplier agrees not to offer the goods on its own website at a lower price or on better terms. This protection incentivises the PCW to invest in demand-enhancing features, creating an accessible platform through which search costs are minimised and consumers can compare price and other non-price indicators (such as customer ratings, service and quality). Absent adequate safeguards, customers may use the PCWs to learn about the product or its characteristics, yet subsequently complete the transaction directly on the supplier's website or through other channels. Such externality would undermine investment and efficiency downstream - as the PCW will not see a return on its investment.

In addition to its role in resolving the hold-up problem, parity supports risk-sharing between upstream and downstream operators. The size of the investment by the PCW depends upon both the breadth of the protection afforded to the downstream platform, and the level of horizontal competition to which the PCW is exposed. Other benefits and efficiencies associated with MFNs include their role in preventing delays in transacting - removing uncertainty as to the availability of better alternative bargains - and in reducing transaction

\footnotetext{
${ }^{6}$ Presentation by Hans W. Friederiszick, 'Competition Policy in Modern Retail Markets' The Antitrust Enforcement Symposium (Oxford, June ca.com/sites/default/files/competition_policy_in_modern_retail_markets_0.pdf > .

${ }_{7}^{7}$ Meta-search engines do not act as agents which conclude the purchase, but rather as an information hub from which customers are redirected to a supplier or agent.
} 
costs by avoiding the need for a constant negotiation of terms between the contracting parties. $^{8}$

The adequate balance between the protection afforded by MFNs and the need to facilitate and secure investment and innovation will be explored in detail later in the paper. At this stage, it is sufficient to note that absent such protection - narrow or wide - the risk of being undercut by rivals or suppliers could lead to a hold-up-problem and would likely stifle investment downstream. ${ }^{9}$ The short-term gain which the supplier or competitor obtains when free-riding, would ultimately result in long-term inefficiency, absorbed by the market as a whole. ${ }^{10}$ Failure to address this problem may undermine PCWs and consequently inhibit their contribution to information flow, access and competitive market dynamics.

\section{The beneficial effects of PCWs}

The presence of an intermediary - the PCW - provides a range of distinct benefits to customers and to competitive dynamics.

The presence of such a platform often improves information flows by collating and aggregating quantitative and qualitative data about suppliers, price and product characteristics. Such data is often provided in multiple languages, supporting access to retailers and distributors worldwide. Further, as modern markets are often characterised by differentiated products and services, the availability of an aggregated information hub is of central significance; it makes it easier for users to compare offerings and identify the best bargain. This promotes competition on price and quality between suppliers, as they strive to

\footnotetext{
${ }^{8}$ Martha Samuelson, Nikita Piankov, Brian Ellman, 'Assessing the effects of most-favored nation clauses' (28 March 2012) ABA Section of Antitrust Law Spring Meeting $<$ http://www.analysisgroup.com/uploadedfiles/content/insights/publishing/samuelson_mfn_springaba_2012.pdf $>$ accessed 2015; Jonathan B. Baker and Judith A. Chevalier, 'The Competitive Consequences of Most-FavoredNation Provisions' (15 April 2013) Antitrust Magazine, Vol. 27, No. 2, 2013 $<$ http://ssrn.com/abstract=2251165> accessed 10 Sep 2015.

9 MFNs can be used to deter rent-seeking delays and hold-up problems where market information such as demand, value, or costs would be discovered after contracts are concluded. See: Steven C. Salop and Fiona Scott Morton, 'Developing an Administrable MFN Enforcement Policy' (2013) Antitrust, Vol. 27, No. 2, 2013, 15; Jonathan B. Baker and Judith A. Chevalier, 'The Competitive Consequences of Most-Favored-Nation Provisions' (April 15, 2013) Antitrust Magazine, Vol. 27, No. 2, 2013 〈http://ssrn.com/abstract=2251165> accessed 22 Oct 2015.

${ }^{10}$ For instance, externality could undermine PCWs investment in pay-for-click advertising, thus reducing access and visibility of upstream suppliers. The limited competition upstream may result in upward pressure on price, to the detriment of customers.
} 
increase sales. Importantly, the presence of PCWs makes it harder for suppliers to take advantage of ill-informed customers who are subjected to high information costs.

The facilitation of information flows contributes to a reduction in search costs. ${ }^{11}$ Users are able to access information, often in their own language, which would not otherwise be easily available. Customers may access information and run search queries without being required to contact the suppliers during normal business hours. ${ }^{12}$ Where, therefore, the presence of high search costs leads to market breakdown, PCWs provide an important means to reduce costs and facilitate search and switching.

The availability of free and easy to reach information can generate substantial allocation efficiencies and increase net social surplus, as buyers are able to locate the sellers that better meet their needs. ${ }^{13}$ This, in turn, supports a competitive dynamic, as suppliers are faced with well-informed buyers who are aware of the market offerings. This pressure also supports greater investment in services, quality and innovation. Firms that interact with well-informed customers are incentivised to invest in order to improve their competitive position.

In its investigation into hotel accommodation and online travel agents, the UK Office of Fair Trading (OFT) ${ }^{14}$ considered the high degree of price transparency and the low costs associated with price searches on the Internet. It noted that ' $[\mathrm{t}]$ he Internet allows for a much swifter search and comparison across a wide variety of choice factors including price, dates, quality and location', ${ }^{15}$ and that ' $[\mathrm{t}]$ he Internet brought about price transparency across the market, enabling consumers to identify the best deal, i.e. the lowest price for any given hotel room, at very low search costs.... 16

\footnotetext{
${ }^{11}$ For economic literature and review of search costs see: OECD, Vertical Restraints for Online Sales (DAF/Comp(2013)13, 12 September 2009) page 17.

${ }^{12}$ Consumer Futures, 'Price comparison websites: consumer perceptions and experiences' (Consumer Futures, July 2013) page $35<$ http://www.consumerfutures.org.uk/files/2013/07/Price-Comparison-Websites-Consumerperceptions-and-experiences.pdf $>$ accessed 6 Nov 2015.

${ }^{13}$ J. Yannis Bakos, 'Reducing Buyer Search Costs: Implications for Electronic Market Places' [1997] 43 (12) Management Science 1, 5.

${ }^{14}$ The OFT ceased to exist on 1 April 2014 and was succeeded by the Competition and Markets Authority. The OFT investigation was opened in September 2010. The Statement of Objections was issued in July 2012.

${ }^{15}$ OFT Statement of Objections, Annex 1, para 1.15, as cited in the Competition Appeal Tribunal judgment Skyscanner Limited v Competition and Markets Authority Case No. 1226/2/12/14, 26 Sep 2014, [2014] CAT 16, 31-32.

${ }^{16}$ OFT Statement of Objections, Paras $1.14-1.15$, as cited in the Competition Appeal Tribunal judgment Skyscanner Limited v Competition and Markets Authority Case No. 1226/2/12/14, 26 Sep 2014, [2014] CAT 16, 31-32.
} 
The reduction in search costs and the availability of better information support a reduction in the market power of sellers and a reduction in price premiums and in seller profit margins. ${ }^{17}$ This would be the case, in particular, when a supplier's market power is the result of high information costs. In such cases, the introduction of a web-aggregator would produce a significant change to market dynamics and exert downward pressure on price. Illustrative is the launch of a comparison website in the UK dedicated to extended warranties. This information website was created following an investigation by the UK Competition Commission which identified a deficiency in the availability of relevant information, which undermined the competitive process. ${ }^{18}$

When the PCW provides comparison tools and reviews, it may also diffuse attempts by distributors to 'overcomplicate' their offering in order to increase information costs. Improvements to, and the simplification of, information flow about differentiated products also reduces switching costs, thereby increasing the mobility of customers, enhancing competition between suppliers and creating further downward pressure on price.

In addition to 'customer related benefits', PCWs also provide a range of distinct benefits to the upstream suppliers which use their services.

First and foremost, PCWs serve a crucial function of risk and cost mitigation. This is of particular significance for suppliers who would otherwise be exposed to excessive risk and costs associated with online advertising and commerce. For instance, these suppliers may lack the economies of scale to achieve a high conversion rate and return on investment in online advertising. ${ }^{19}$ They may also lack the requisite sophistication needed for costeffective bidding on keywords which are central for search marketing.

\footnotetext{
${ }^{17}$ J. Yannis Bakos, 'Reducing Buyer Search Costs: Implications for Electronic Market Places' [1997] 43 (12) Management Science 1, 13; Joseph E Stiglitz, 'Imperfect information in the product market' in R. Schmalensee and R. D Willig (eds), Handbook of Industrial Organisation (Volume 1) (Elsevier Science Publishers, 1989) 769; J. Yannis Bakos, ‘A Strategic Analysis of Economic marketplaces’ [1991] MIS Quarterly 295.

${ }^{18}$ Competition Commission, Extended warranties on domestic electrical goods: A report on the supply of extended warranties on domestic electrical goods within the UK - Volumes 1, 2 and 3 (Competition Commission Report, Cm 6089, December 2003); The OFT accepted undertakings in lieu of the reference to the Competition Commission. Accordingly, a dedicated information site was launched: www.compareextendedwarranties.co.uk.

${ }^{19}$ When a hotel invests in pay-per-click advertising, it will only achieve conversion if the customer is interested in that hotel. On the other hand, an OTA is likely to achieve higher conversion rates as it represents a large number of hotels. Its investment in advertising is therefore less risky and more likely to be recouped.
} 
The hotel industry provides an illustrative example of such function. PCWs engage in sophisticated and ongoing bidding for 'search words' on search engines as part of their supply of demand-enhancing services for suppliers. As an intermediary, representing a large number of hotels, they are able to obtain higher conversion rates - that is, the ability to turn visitors into customers. This function has significant effects on small- and medium-sized hotels as they would otherwise find it too costly and risky to engage in direct advertising and absorb the high cost of pay-per-click advertising. Search engines would require the hotels to pay for any click on the advertisement, regardless of whether a transaction followed. With the low conversion rates - that is, the ability to turn visitors into customers - a payment for every click may prove uneconomical. To better appreciate the costs involved, note for instance the cost of common search terms such as 'Hotel Paris' which may reach EUR 25 per click, regardless of whether that click led to a subsequent sale. Absent the presence of an intermediary, some suppliers may have limited or no 'search marketing' - thus limiting the availability of information from which customers may benefit.

In contrast, by acting as an intermediary which is able to invest in large scale advertising, the PCW facilitates cost-based efficiencies and mitigates the risks to which suppliers are exposed, as they only pay a commission for a successful transaction. ${ }^{20}$ Absent this function, small and medium entities would have played a more limited role in the competitive process, leaving the centre stage for the larger entities which are better placed to absorb the costs and risks and would benefit from a higher conversion rate.

In addition to their role in reducing suppliers' costs and risks, PCWs also provide a safe environment in which customers may conclude the deal. For instance, a web-aggregator's payment system, guarantee and ease of transaction may prove crucial for new, unknown entrants. Customers who would otherwise be apprehensive about a new entrant or small supplier, may be more willing to engage in a transaction when the web-aggregator offers its own payment system and guarantees.

\footnotetext{
${ }^{20}$ In addition, the PCW is likely to present greater sophistication and efficiencies when bidding, which would result in higher conversion rate.
} 
PCWs also help reduce transaction delays by preventing consumers from delaying their purchases in the hope of a better deal. ${ }^{21}$ The incentive for consumers to stall their purchases is reduced if all major suppliers sell through a single web-aggregator. The speed of transactions may further be increased by a reduction in bargaining time, with the costs associated with bargaining also undergoing a significant reduction. ${ }^{22}$ This would be particularly significant where the supplier's costs change regularly or there is a large variation in products.

Further benefits associated with PCWs concern their role in providing a valuable channel for upstream entry and expansion. PCWs enable smaller suppliers to reach customers and inform them of their offering. Such information is displayed on the platforms (websites/apps) of PCWs and their distribution partners, in different languages and with local prices, thus further supporting entry and expansion into new markets. These sellers may have found it impossible to successfully enter the market absent the presence of an intermediary. Indeed, a report for Consumer Futures found that consumers said, 'they would only know to contact a few companies for any given product or service, but on [PCWs] they get a wider range of options to choose from. ${ }^{23}$ The range of suppliers and products searchable on these platforms often reveals unknown sellers and products to which customers would not otherwise have been exposed. The facilitation of entry further enhances competitive pressure upstream, to the benefit of consumers. ${ }^{24}$

Overall, PCWs facilitate sales, economies of scale and efficiencies in distribution, marketing and promotion. They do so at both national and international levels, thus widening the reach of suppliers and widening the customer base. As these supplier-focused efficiencies lower costs and risks for suppliers, they enable them to offer lower prices to the benefit of customers.

\footnotetext{
${ }^{21}$ Jonathan B. Baker and Judith A. Chevalier, 'The Competitive Consequences of Most-Favored-Nation Provisions' (15 April 2013) Antitrust Magazine, Vol. 27, No. 2, 2013 〈http://ssrn.com/abstract=2251165> accessed 6 Nov 2015.

${ }^{22}$ Martha Samuelson, Nikita Piankov, Brian Ellman, 'Assessing the effects of most-favored nation clauses' (28 March 2012) ABA Section of Antitrust Law Spring Meeting, page 2 $<$ http://www.analysisgroup.com/uploadedfiles/content/insights/publishing/samuelson_mfn_springaba_2012.pdf $>$ accessed 6 Nov 2015.

${ }^{23}$ Consumer Futures, 'Price comparison websites: consumer perceptions and experiences' (Consumer Futures, July 2013) page $35<$ http://www.consumerfutures.org.uk/files/2013/07/Price-Comparison-Websites-Consumerperceptions-and-experiences.pdf $>$ accessed 6 Nov 2015.

${ }^{24}$ Unlike with suppliers, a PCW can offer one app in which all of its suppliers are made available which a consumer more easily will find and download in an app-store and subsequently use. Suppliers either do not have an app, or the app is impossible to find in the app-store or it is unpractical for a consumer to download and use one app for each supplier.
} 


\section{Wide Parity - All that Glitters is not Gold}

As illustrated above, PCWs enable a competitive market dynamic and can contribute to consumer welfare, with MFNs being instrumental to their operation. Yet, the restrictions afforded by MFNs may also undermine potential positive welfare gains, and therefore require careful review and balancing.

Evidently, the welfare effects of a parity clause depends upon its scope, application, the level of competition at different levels of the distribution chain, and the market environment. ${ }^{25}$ This complexity, by its nature, requires a fact-intensive case-by-case analysis. ${ }^{26}$ Accordingly, generalisations regarding theories of harm must be discussed with the clear caveat that different realities may entail different effects. With that in mind, one can outline four core exclusionary and collusive anticompetitive effects commonly associated with agency-model wide MFNs.

\section{Excessive intermediation}

While PCWs increase transparency and therefore competition among suppliers, that competition may not always lead to lower prices. Excessive intermediation may occur when the PCW operates under an agency/merchant model, charging a fee for each transaction, and a wide MFN clause is in place. In such a scenario, the downstream PCW may be incentivised to increase its fees or be dis-incentivised from reducing them. This could be the case when the wide MFN protects the PCW from the risk that a supplier will react to an increase in the commission it has to pay, by increasing the product price on that platform only (which would, of course, make the price offered on that platform less attractive in comparison to the price offered on other PCWs).

\footnotetext{
${ }^{25}$ For a review of the range of factors which play a role in the assessment, see Steven C. Salop and Fiona Scott Morton, 'Developing an Administrable MFN Enforcement Policy' (2013) Antitrust, Vol. 27, No. 2, $2013,15$.

${ }^{26}$ On the necessity of case-by-case assessment, see, for instance: Lear, Can 'Fair' Prices Be Unfair? A Review of Price Relationship Agreements (OFT Report, OFT1438, September 2013) 6.75.
} 
As a result, one may witness a softening of competition between online platforms regarding the charges they levy on their suppliers. ${ }^{27}$ As noted by Edelman and Wright:

... the increase in retail prices all buyers face as a result of intermediation cancels out the extra benefits they obtain [from that intermediation]... Buyers participate, even though they are jointly worse off from doing so, due to a coordination failure... If buyers could coordinate, they would take into account the higher price that results from their individual decisions to join the intermediary, and collectively they would prefer not to join the intermediary. ${ }^{28}$

Moreover, competition between online platforms would not necessarily reduce excessive intermediation:

First, when [an] intermediary... charges sellers higher fees than are charged by competing intermediaries, price coherence ensures that the buyers that choose rival intermediaries share those higher fees... Second, with price coherence, an intermediary does not face a reduction in demand as it raises its fees to sellers... Third, by raising its fees to sellers and raising the benefits it offers buyers, an intermediary attracts buyers away from other intermediaries with lower benefits-even though those intermediaries have lower fees to sellers. As a result, excessive fees and benefits persist in equilibrium, and too many buyers join intermediaries. ${ }^{29}$

The UK Competition and Markets Authority observed these welfare effects in its review of the private motor insurance sector:

Generally, we expected that higher commission fees would lead to higher policy premiums because there was likely to be some pass-through of costs to

\footnotetext{
${ }^{27}$ For an economic modelling on the way wide MFNs may raise platform fees and retail prices, see: Andre Boik and Kenneth S. Corts, 'The Effects of Platform MFNs on Competition and Entry' (2013) University of Toronto $\langle$ http://economics.yale.edu/sites/default/files/corts 17-oct-2013.pdf> accessed 6 Nov 2015; Justin P. Johnson, 'The Agency Model and MFN Clauses' (2014) <http://papers.ssrn.com/sol3/papers.cfm?abstract id=2217849> accessed 6 Nov 2015.

${ }^{28}$ Benjamin Edelman and Julian Wright, 'Price Coherence and Excessive Intermediation' (March 2015) Quarterly Journal of Economics 130 no. 3 (2015) <http://www.benedelman.org/publications/pricecoherence2015-03-12.pdf> accessed 12 Oct 2015.

${ }^{29}$ Id $19-20$.
} 
premiums... irrespective of the rate of pass-through, the PCW with the wide MFN could continue to increase commission fees until the price of the policy was too high from the point of view of the PCW. Premiums across the market might increase up to the point at which [private motor insurance] providers exercised their 'outside option', which would be to withdraw from listing on the PCW with the wide MFN and to seek to attract customers from other sources... ${ }^{30}$

Indeed, excessive intermediation - that is, higher commission - is less likely to occur, even under wide MFN, when viable outside options are available, when the supplier benefits from buyer power, when de-listing becomes a viable option for a supplier, or when a risk of significant new PCW entry is likely.

When an increase in commission does persist, that increase could be reflected in a price increase by the supplier. Note that the supplier is likely to resist an increase in the price, in order to retain its competitive position against other brands. Accordingly, it may prefer to absorb the increase in the charge. However, if the increase in commission is too high, the supplier is likely to terminate the relationship with the PCW or increase the price across the board - since, under the wide MFN, price parity with other platforms is guaranteed.

\section{Limits on low cost entry to the downstream market}

A second theory of harm associated with wide MFNs concerns the possibility that the presence of wide parity clauses, combined with an agency model, would hinder entry by PCWs into the downstream market.

\footnotetext{
${ }^{30}$ UK Competition and Markets Authority (CMA), Private motor insurance market investigation: Final report (CMA Report, September 2014) 8.42, 8-14 < https://assets.digital.cabinetoffice.gov.uk/media/5421c2ade5274a1314000001/Final_report.pdf $>$; on the use of wide parity in this sector, note comments made by Graham Donoghue, managing director of financial services at Money Supermarket: 'I cannot offer my consumers [lower prices] by investing some of my commission and margin back into price. I cannot offer them a better price because these wide clauses are stopping me from doing that. It is ridiculous that our peers have attempted to lock down some large insurers in what we think is a very harmful way.' See: Stephanie Denton, 'Money Supermarket slams rivals' use of wide 'most favoured nation' clauses' (Post, 25 September 2013) < http://www.postonline.co.uk/post/news/2296520/money-supermarket-slams-rivals-use-ofwide-most-favoured-nation-clauses $>$ accessed 12 Oct 2015.
} 
This may be the case when a new platform wishes to adopt a low cost model, yet is unable to secure lower prices from distributors who are already committed under an existing wide parity agency model. As the supplier is obliged to offer the incumbent PCWs any discount it offers on the entrant's platform, a reduction in price would not benefit the entrant and would also work against the supplier's profit maximisation incentive. Similarly, a reduced commission charged by a new entrant would not result in a reduced price offering on its platforms, since the supplier cannot reward lower commission by offering a lower price. A lower price offer would trigger a demand for price parity from other PCWs under the terms of their wide MFNs. Further, it reduces the economic incentive for suppliers to take up the services of other small or marginal PCWs and may chill incentives to invest and innovate.

Note, however, that when the potential entrant has a business model relatively similar to the incumbents, MFNs could actually encourage entry. ${ }^{31}$ In such case the presence of wide MFNs on a given market could signal to potential entrants that the existing business model is successful. Further, it will provide an entrant with some assurance that following its investment, it will not be undercut by other PCWs or be subjected to free-riding.

\section{Price uniformity}

Another possible effect often linked to wide MFNs is the increased likelihood of industrywide price uniformity. After all, under an agency model, the imposition of wide MFNs by leading platforms would result in identical pricing and terms. The supplier lacks any incentive to reduce its price on other platforms, because this would result in an across-theboard reduction to all online platforms that benefit from a wide MFN.

The actual effects of price uniformity depend, among other things, upon the number and size of PCWs that benefit from wide MFNs, the number of suppliers tied to such agreements, the bargaining powers of suppliers and PCWs, (timely) compliance by suppliers with MFNs and the availability of meta-search tools. Importantly, the possible effects of price uniformity depend on the level of inter-brand competition. Limits to intra-brand competition are likely to have limited effects when inter-brand competition is present. When competition between

\footnotetext{
${ }^{31}$ Andre Boik and Kenneth S. Corts, 'The Effects of Platform MFNs on Competition and Entry' (2013) University of Toronto 〈http://economics.yale.edu/sites/default/files/corts_17-oct-2013.pdf> accessed 12 Oct 2015.
} 
different suppliers exists, the supplier will be incentivised to lower the retail price it sets, in order to ensure its viability. In such cases, uniform prices, even when present, are likely to be competitive.

A notable example of objection by a competition agency to the uniformity fostered by wide MFNs maybe found in the HRS case. There, the uniformity in price that resulted from the use of wide MFNs was condemned by the Bundeskartellamt (the German Federal Cartel Office). It held that the MFNs used by HRS - the Hotel Reservation Service - constituted a significant restraint of competition. ${ }^{32}$ The Bundeskartellamt opined that the economic effect of the MFN in that case was 'similar to direct collusion between the hotel portals." ${ }^{33}$ Subsequently, HRS was obliged to terminate the MFNs, although no fine was imposed. Indeed, as illustrated in literature, agency wide MFNs could, under certain market conditions, result in price uniformity generating effects similar to those exhibited under resale price maintenance. $^{34}$

\section{Limits on innovation and investment}

While parity clauses are aimed at minimising externalities and increasing investment and innovation downstream, wide parity clauses may theoretically have the potential to limit such investments. Admittedly, this theory of harm is the weakest of all four. It suggests that under wide parity, the incentive to invest is dampened, as investment will not result in lower retail prices and will fail to attract more customers to the PCWs. According to this theory of harm, absent wide MFNs, a downstream web-aggregator may be incentivised to invest in demandenhancing features and other efficient measures which would increase its appeal to upstream suppliers.

\footnotetext{
32 Bundeskartellamt, HRS-Hotel Reservation Service, Point 1. Translated decision $<$ http://www.bundeskartellamt.de/SharedDocs/Entscheidung/EN/Entscheidungen/Kartellverbot/B9-66-

10.pdf? blob=publicationFile $\& v=3>$. The Agency noted that, due to the significant restraint of competition on the market 'between the hotel portals and between the hotels; it can therefore be considered irrelevant whether this restraint is a restraint by object.'

${ }^{33} I d$, Point 157.

${ }^{34}$ Amelia Fletcher and Morten Hviid, 'Retail price MFNs: Are they RPM 'at its worst'?' (2014) CCP Working

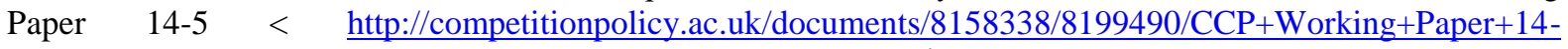
5.pdf/0ec21eee-12ca-4bc8-b3ea-d5076ab264af > accessed 2015; Øystein Foros, Hans Jarle Kind, Greg Shaffer, 'Turning the Page on Business Formats for Digital Platforms: Does Apple's Agency Model Soften Competition?' (2013) CESifo Working Paper Series No. 4362 $<$ http://papers.ssrn.com/sol3/papers.cfm?abstract_id=2317715> accessed 6 Nov 2015.
} 
The difficulty with this theory of harm is that it ignores other parameters of competition. Indeed, even when the price is set by the supplier, PCWs are likely to compete on quality and service. In fact, the parity clause provides them with some protection against free-riding, thus further facilitating innovation and investment in demand-enhancing features - offering information in multiple languages, reviews, call centres, advertising services etc. They may also compete through indirect pricing, by offering rewards for returning users. ${ }^{35}$

Where this theory of harm could play a role, is in instances in which a given investment would benefit the upstream supplier but have no beneficial effect on the PCWs or its customers. As noted by the CMA in its Private Motor Insurance Market Investigation, wide MFNs 'reduce the incentives for incumbents and entrants to innovate. PCWs could innovate in ways which lower the costs of business for a [private motor insurance provider] (PMI) selling through their PCW, e.g. by offering better fraud detection measures. Without wide MFN constraints, such innovation would lead to the PMI provider offering lower premiums through that PCW, reflecting the cost savings to the provider of the PCW's innovation. However, if the PMI provider cannot offer policies cheaper to innovative PCWs because of wide MFN clauses with other PCWs, this may reduce the incentive for the PCW to innovate as it would not receive any advantage over its competitors. ${ }^{36}$

\section{Wide Parity - Enforcement Highlights}

The anticompetitive effects described above have been central to the analysis of wide MFNs worldwide. Indeed, a review of the main decisions by competition agencies reveals a consensus as to the possible harmful effects which wide MFNs combined with an agency model may generate.

The most publicised case which involved wide MFNs, and was pursued on both sides of the Atlantic, concerned Apple's use of wide parity in its iBooks Store. Importantly, while of high profile, the case did not address the competitive effects of wide MFNs as such, but focused on Apple's attempt to affect e-book prices. Nonetheless, the case provides an interesting starting point:

\footnotetext{
${ }^{35}$ For instance, Hotels.com Reward programme offers a free night for every 10 nights booked via the platform.

${ }^{36}$ UK Competition and Markets Authority (CMA), Private motor insurance market investigation: Final report (CMA Report, September 2014) $8.39 \quad<$ https://assets.digital.cabinetoffice.gov.uk/media/5421c2ade5274a1314000001/Final_report.pdf> accessed 6 Nov 2015.
} 
In the U.S., the Department of Justice raised concerns regarding the wide MFN clauses and agency models used in agreements between Apple Inc. and leading publishers. ${ }^{37}$ It argued that the agreements were strategically designed to increase e-book prices and, in particular, the price of new releases and New York Times best sellers. ${ }^{38}$ The agreements pressurised Amazon to switch from a wholesale model - in which it controlled the price of e-books and heavily discounted them - to an agency model. On appeal, the Second Circuit considered the unique economic incentives created by the introduction of a wide MFN in this case: ${ }^{39}$

The MFN Clause changed the situation by making it imperative, not merely desirable, that the publishers wrest control over pricing from ebook retailers generally... The publishers recognized that, as a practical matter, this meant that the MFN Clause would force them to move Amazon to an agency relationship... ${ }^{40}$

As indicated above, the case is unique in its characteristics. The agency agreement and the parity clauses were used as part of a wider illegal collusive strategy orchestrated by Apple to force collective action by the publishers. Indeed, the court condemned the agreements 'not because those [MFNs and agency] Contracts themselves were independently unlawful, but because, in context, they provide strong evidence that Apple consciously orchestrated a conspiracy among the Publisher Defendants. ${ }^{, 41}$

\footnotetext{
${ }^{37}$ For an economic modelling approximating the facts of this case, see: Øystein Foros, Hans Jarle Kind, Greg Shaffer, 'Turning the Page on Business Formats for Digital Platforms: Does Apple's Agency Model Soften Competition?' (2013) CESifo Working Paper Series No. 4362 $\langle$ http://papers.ssrn.com/sol3/papers.cfm?abstract_id=2317715> accessed 6 Nov 2015. The authors note that 'control over retail prices should optimally be given to the level in the distribution chain that faces the least competitive pressure if the goal is to dampen competition and increase prices.' They also show that 'pressure would be needed to induce industry-wide adoption of the agency model when competition upstream is sufficiently weak...'.

${ }^{38}$ United States v. Apple Inc., 952 F. Supp. 2d 638, 15647 (S.D.N.Y. 2013).

${ }^{39}$ United States v. Apple, Inc., No. 13-3741-cv (2d Cir. 2015).

${ }^{40}$ Id, Page 28, 29.

${ }^{41} I d$, Page 58. Also see a similar statement by the United States District Court, S.D. New York: 'If Apple is suggesting that an adverse ruling necessarily implies that agency agreements, pricing tiers with caps, MFN clauses, or simultaneous negotiations with suppliers are improper, it is wrong. As explained above, the Plaintiffs have not argued and this Court has not found that any of these or other such components of Apple's entry into the market were wrongful, either alone or in combination. What was wrongful was the use of those components to facilitate a conspiracy with the Publisher Defendants.' United States v. Apple Inc., 952 F. Supp. 2d 638, 708 (S.D.N.Y. 2013).
} 
The European Commission also raised concerns with the strategy used by Apple and the publishers to force Amazon to raise retail prices. With respect to the wide MFN and agency model, the Commission took the view that:

... the retail price MFN clause acted as a joint "commitment device" whereby each of the Five Publishers was in a position to force Amazon to accept changing to the agency model or otherwise face the risk of being denied access to the e-books of each of the Five Publishers. ${ }^{42}$

The Commission accepted commitments offered by Apple and the publishers, which included the termination of the agency agreements, a two year ban on the publishers' ability to obstruct e-book retailers from setting their own prices or offering discounts, and a five year ban on MFNs. ${ }^{43}$

Moving to cases where wide parity was addressed directly, notable is Amazon's use of wide MFNs in its agreements with suppliers. In 2013, the UK Office of Fair Trading (OFT) and the German Bundeskartellamt challenged the use of these provisions. The arrangements in question established a wide prohibition, restricting suppliers' freedom to offer their products at a lower price through competing platforms to Amazon's own. These arrangements extended beyond price and included shipping, discounts and customer service policies. Concerns raised by the agencies included the upward pressure these clauses may have on online platform fees and prices, and the negative effect they may have on potential entrants. ${ }^{44}$ In response to these concerns, Amazon ended its price parity policy across its EU Marketplace. $^{45}$ In 2015 Amazon's use of MFNs came again under scrutiny when the

\footnotetext{
${ }^{42}$ Case COMP/AT-39.847-E-Books, Commission Decision of 25/07/2013, Article 9 Regulation (EC) 1/2003; Commitment decisions concerning all companies involved are available online: $<$ http://ec.europa.eu/competition/elojade/isef/case_details.cfm?proc_code=1_39847>.

${ }^{43}$ Joaquin Almunia, Vice President of the European Commission responsible for Competition Policy, Statement on commitments from Apple and four publishing groups for sale of e-books (European Commission Press Release, 22 October 2015) <http://europa.eu/rapid/press-release_SPEECH-12-955_en.htm> accessed 6 Nov 2015.

${ }^{44}$ OFT, OFT welcomes Amazon's decision to end price parity policy (OFT Press Release 60/13, 29 August 2013) <http://webarchive.nationalarchives.gov.uk/20140402142426/http://www.oft.gov.uk/news-andupdates/press/2013/60-13> accessed 6 Nov 2015; European Commission, Germany and United Kingdom: Antitrust Cases against Amazon formally closed (European Commission Press Release, 2015) $<$ http://ec.europa.eu/competition/ecn/brief/05_2013/amaz_deuk.pdf> accessed 6 Nov 2015.

${ }^{45}$ Id; Bundeskartellamt, Amazon abandons price parity clauses for good (Bundeskartellamt Press Release, 26 November <http://www.bundeskartellamt.de/SharedDocs/Meldung/EN/Pressemitteilungen/2013/26_11_2013_AmazonVerfahrenseinstellung.html\%3Fnn\%3D3599398> accessed 6 Nov 2015.
} 
European Commission opened a formal investigation into Amazon's e-book distribution arrangements. Among other things, the Commission considered the use of wide-MFNs which grant Amazon the right to terms and conditions at least as good as those offered to its competitors, and 'seem to shield Amazon from competition from other e-book distributors'. ${ }^{46}$

Another notable example concerns the use of wide parity clauses in the hotel industry across Europe. The use of parity clauses by Online Travel Agents (OTAs) has attracted much attention in recent years. These intermediaries are used by consumers to search, compare and book hotel accommodation and holidays. In addition, they play a key role in ensuring the visibility of hotels vis-à-vis consumers through the OTAs' own website and by advertising on search engines. $^{47}$

In 2013, the Bundeskartellamt reached a decision concerning the use of broad parity clauses by the hotel portal HRS. ${ }^{48}$ The broad parity clauses in question required hotel partners to guarantee that the price offered on HRS was no greater than the cheapest rate offered by or for the hotel on other online booking and travel platforms, or on the hotel's own web pages and offline sale channels. ${ }^{49}$ The MFNs covered parity not only in price, but also in room availability, booking conditions and mobile applications. ${ }^{50}$ The Bundeskartellamt noted that HRS had strictly monitored hotels' adherence to the terms of these clauses and threatened to terminate contractual relations with hotels that failed to apply the parity. It subsequently held that the wide MFNs at issue were set to directly restrict the price-setting freedom of hotels on the other sales channels. ${ }^{51}$ It found that the wide MFNs removed the economic incentive for the OTA to lower commissions to the hotels or to adopt new sales strategies. ${ }^{52}$ Further, it

\footnotetext{
${ }^{46}$ European Commission, Antitrust: Commission opens formal investigation into Amazon's e-book distribution arrangements' Brussels (European Commission Press Release, 11 June 2015) <http://europa.eu/rapid/pressrelease_IP-15-5166_en.htm> accessed 12 Oct 2015.

${ }^{47}$ Generally, it is only the large hotel chains which directly advertise with search engines and web-aggregators. Most hotels would appear on the search engines through OTAs which list them on these sites.

48 HRS-Hotel Reservation Service (20 December $\quad 2013) \quad$ B $\quad 9 \quad-\quad 66 / 10$ <http://www.bundeskartellamt.de/SharedDocs/Entscheidung/EN/Entscheidungen/Kartellverbot/B9-6610.pdf;jsessionid=9BE25EB94E65170764A6BA609635D89A.1 cid378? blob=publicationFile \&v=3 > ${ }^{49} I d$, Point 30, 169.

50 That extension of the MFN had been the subject of a complaint by BookitNow! Services GmbH, which considered that it had been hindered in launching its mobile hotel app on the market by the MFN clauses of HRS.

51 HRS-Hotel Reservation Service (20 December 2013) B $9 \quad-\quad 66 / 10, \quad$ Point 49 < http://www.bundeskartellamt.de/SharedDocs/Entscheidung/EN/Entscheidungen/Kartellverbot/B9-6610.pdf;jsessionid=9BE25EB94E65170764A6BA609635D89A.1_cid378? _ blob=publicationFile\&v=3>. ${ }^{52}$ Id, Point 9.
} 
considered that wide MFNs make market-entry by new competitors more difficult and restrict opportunities to open new hotels.

Commitments offered by HRS to refrain from applying the wide parity clause for a five-year period and to adjust the contracts with the affiliated hotels were rejected. The agency did not regard a temporary, yet complete, abandonment of the price parity provision as an adequate solution. It further raised doubts as to the sincerity of HRS' commitments and their likely implementation. ${ }^{53}$ It opined that only a prohibition order would ensure that HRS' wide MFNs were removed. $^{54}$

In January 2015, the Düsseldorf Higher Regional Court upheld the Bundeskartellamt decision and condemned the restrictive effect that a parity clause has had on the hotel companies' freedom to act. ${ }^{55}$ Interestingly, the court also raised doubts regarding HRS' claim that wide MFNs created crucial incentives for ongoing investment in the quality of the downstream platform. It opined that investment would not necessarily be undermined, even if the removal of MFNs and consequent free-rider problems reduced sales downstream. In such a case, the Court noted, it would be in the PCW's commercial interest to improve its market position through investment in quality, special offers and promotional activities:

The more users a platform attracts, on both the supply side and the demand side, the more appealing it becomes for new users in turn. Even without restricting price differentiation by the hotels, therefore, there is a considerable incentive for [the OTA] to invest in the quality of the portal's offering. ${ }^{56}$

While the Court's condemnation of the wide parity is convincing, its overreaching statement, which ignores the risk of free-riding, is intriguing. Is it truly the case that a downstream operator will continue to invest despite externalities and reduced conversion rates? After all, if suppliers are given a free reign to undercut the price they themselves have set on the PCW, why would the downstream PCW continue to invest in promoting their business? No doubt, free-riding will pose a dilemma for the PCW as it will have to continue investing in services to maintain traffic and a user-friendly interface. Yet, overtime, it seems reasonable to expect

\footnotetext{
${ }^{53} I d$, Point 265.

${ }^{54} I d$, Point 263-267.

${ }_{55}^{55}$ Kart 1/14 (V) (9 January 2015) Higher Regional Court of Düsseldorf, Point 83, VI.

${ }^{56} \mathrm{Id}$, Point 181 (unofficial translation).
} 
that under the existing agency model, such free-riding would undermine the PCW's profitability and subsequently its investment downstream.

Another noteworthy case in the hotel industry concerned the online travel agent Booking.com. A large number of competition agencies across Europe raised concerns regarding the use of wide MFNs by Booking.com and its support of wide parity.

In Germany, the Bundeskartellamt raised concerns as to the restriction of competition triggered by use of the wide MFNs. ${ }^{57}$ In doing so, it noted that the Düsseldorf Higher Regional Court endorsed the agency's findings in the earlier HRS case. Furthermore, the Bundeskartellamt rejected commitments offered by Booking.com to reduce the scope of its best price clause and establish a narrow parity. ${ }^{58}$ It subsequently issued a prohibition decision. ${ }^{59}$ Booking.com has indicated its intention to appeal the decision. ${ }^{60}$ In contrast to the developments in Germany, however, binding commitments offered by Booking.com were accepted by the French, Swedish and Italian competition authorities, and offered in all other Member States. These developments will be explored in greater detail in Section VI below.

Moving away from the hotel sector, another interesting example of the enforcement approach to wide MFNs is the U.S. Department of Justice (DOJ) antitrust lawsuit against the insurer, Blue Cross Blue Shield of Michigan (BCBSM). ${ }^{61}$ The case concerned BCBSM's use of wide MFNs in its agreements with health providers. The MFNs required contracted hospitals either to charge BCBSM no more than they charge its competitors, or to charge the competitors a specified percentage more than they charge BCBSM. The DOJ found the MFNs to stifle

\footnotetext{
${ }^{57}$ Statement of objections issued on 30 March 2015.

${ }^{58}$ Also worthy of note is the Bundeskartellamt inquiry into energy-comparison portals and concerns raised as to the use of wide parity between Vrivox, a German electricity and gas web-aggregator, and its suppliers. Vrixox agreed to remove all of its http://www.bundeskartellamt.de/SharedDocs/Meldung/EN/Pressemitteilungen/2015/03_06_2015_Verivox.html ?nn=3599398> accessed 6 Nov 2015.

$\overline{59}$ Bundeskartellamt, Narrow 'best price' clauses of Booking also anticompetitive (Bundeskartellamt Press Release, 23 December 2015)

<http://www.bundeskartellamt.de/SharedDocs/Meldung/EN/Pressemitteilungen/2015/23_12_2015_Booking.co m.html> accessed 7 Jan 2016.

${ }^{60}$ PR Newswire, Booking.com Announces Intent to Appeal Bundeskartellamt Ruling (PR Newswire, 23

December 2015) <http://www.prnewswire.com/news-releases/bookingcom-announces-intent-to-appealbundeskartellamt-ruling-563356891.html> accessed 7 Jan 2015.

${ }^{61}$ United States v. Blue Cross Blue Shield of Michigan, 809 F. Supp. 2d 665 (E.D. Mich. 2011); Department of Justice Office of Public Affairs, Justice Department Files Antitrust Lawsuit Against Blue Cross Blue Shield of

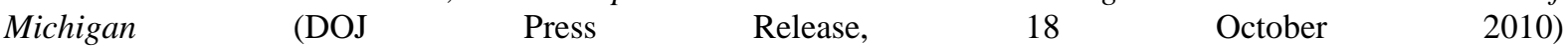
<www.justice.gov/atr/public/press_releases/2010/263227.htm> accessed 20 Sep 2015.
} 
competition and result in higher health insurance prices for Michigan consumers. As a result, the DOJ alleged that BCBSM's MFNs led hospitals to increase their prices to BCBSM's competitors and insulated BCBSM from competition. ${ }^{62}$ Following legislation by the State of Michigan, which prohibited health insurers from using MFNs in contracts with health care providers, the DOJ dismissed its antitrust lawsuit. ${ }^{63}$ A class action launched by small businesses and individuals against BCBSM alleging violation of antitrust laws was settled in April $2015 .^{64}$

Overall, the discussion of wide MFNs reveals a large degree of consensus as to the possible harmful effects they generate, and has led competition agencies to condemn such practices. It is worth noting that such condemnation was not the result of an assumed illegality, but has been the result of case-by-case analysis, which took into account the market and contract characteristics, and subsequently appraised the likely effect on competition and consumer welfare.

\section{Narrow Parity - The Competitive Effects}

In contrast to wide MFNs, narrow MFNs constitute a less intrusive restriction on pricing or terms. Such arrangements are often limited to creating a link between the online price and terms available on the supplier's website, on the one hand, and on the PCW on the other. These parity clauses may, at times, also include reference to the supplier's offline price. At other times they may be restricted in their scope, for instance, when they are dis-applied to groups of customers to which the supplier may offer better prices or terms.

\footnotetext{
${ }^{62} \mathrm{Id}$; for similar concerns note the civil antitrust lawsuit launched by the DOJ against American Express, MasterCard and Visa (4 October 2010); United States v. American Express Co., No. 1:10CV-4496 (21 December 2010) <http://www.justice.gov/file/485836/download>; ); Department of Justice Office of Public Affairs, Justice Department Sues American Express, Mastercard and Visa to Eliminate Rules Restricting Price Competition; Reaches Settlement With Visa And Mastercard (DOJ Press Release, 4 October 2010) 〈http://www.justice.gov/sites/default/files/atr/legacy/2010/10/04/262867.pdf > accessed 22 Sep 2015.

${ }^{63}$ The MFN ban imposed by the State of Michigan took effect on January 2014; Department of Justice Office of Public Affairs, Justice Department Files Motion to Dismiss Antitrust Lawsuit Against Blue Cross Blue Shield of Michigan After Michigan Passes Law to Prohibit Health Insurers from Using Most Favored Nation Clauses in Provider Contracts (DOJ Press Release, 25 March 2013) <www.justice.gov/opa/pr/justice-department-filesmotion-dismiss-antitrust-lawsuit-against-blue-cross-blue-shield $>$ accessed 22 Sep 2015.

${ }^{64}$ Shane Group v. BCBSM Settlement $<$ https://www.michiganhospitalpaymentslitigation.com/> accessed $22 \mathrm{Sep}$ 2015; Matthew Bultman, 'Controversial \$30M Blue Cross Antitrust Settlement Approved' (Law360, 1 April 2015) <http://www.law360.com/articles/638293/controversial-30m-blue-cross-antitrust-settlement-approved> accessed 22 Sep 2015.
} 
Importantly, narrow MFNs are distinguishable from wide MFNs in that they only concern the relationship between a single web-aggregator and a single supplier, and do not govern the relationship between that supplier and other PCWs. As such, they may be regarded as establishing only a single linear link, as opposed to the multi-vector-net fostered by wide MFNs.

This difference results in fundamental variations in effects between wide and narrow parity. Narrow parity, based on a single linear link, does not give rise to many of the concerns linked to wide parity multi-vector-net.

First and foremost, under the limited protection offered by narrow MFNs, the web-aggregator has no guarantee that an increase in its commission would not result in a competitive disadvantage. On the contrary, each web-aggregator is incentivised to offer more competitive terms in its negotiations with suppliers. After all, under an agency model, a lower commission will incentivise suppliers to lower their prices on that PCW. Since under narrow parity, the supplier is not required to match its best price and offer it elsewhere - lower prices can be offered in exchange for lower commission. This benefits both the supplier and the $\mathrm{PCW}$, as it increases the volume of business through the platform.

Further, this competitive dynamic enhances competition between PCWs downstream - each competing to provide better demand-enhancing features and lower commissions. Similarly, it enhances intra-brand competition upstream, as suppliers are able to offer lower prices on different platforms. Similarly, inter-brand competition is intensified.

In addition, a removal and absence of availability parity (with other PCWs) gives the supplier the power and tools to effectively yield and differentiate prices across multiple platforms and/or lower commission.

Importantly, the narrow parity and absence of availability parity which make these competitive effects possible, is not likely to undermine investment downstream. PCWs still retain protection against direct free-riding by their supplier and are thus incentivised to offer demand-enhancing features. Further, as they compete horizontally against other PCWs, they are incentivised to improve the scope and quality of their services. 
These positive effects should be considered in conjunction with two theories of harm which are associated with narrow parity. Although narrow in scope, these theories should be acknowledged:

\section{Network effects and competition on commissions}

The first theory of harm concerns the possible horizontal effects which may be present when the amalgamation of several single linear links generate a network effect. According to this theory of harm, the contractual freedom of upstream suppliers to offer different prices and terms on various PCWs, will not foster price competition between those PCWs. That may be the case, in particular, when: [1] an important proportion of sales are made through the supplier's own website; and [2] a number of narrow MFNs are in place between the supplier and the online platforms - each linking the price offered on a PCW to the supplier's price.

Consider the following scenario: A supplier is using several PCWs with narrow parity conditions. To limit the instances in which it is required to pay a commission to the PCWs, the supplier is keen to attract customers directly to its own website. To do so, the price on its website cannot be higher than that on PCWs. As a result, through a 'hub-and-spoke' effect, a de-facto floor price may be established for the given service or product.

Further, this combined network effect may discourage reduction in commission or lowcommission-fee entry. This is because any commission increase which results in a price increase would also raise the upstream sale price on the supplier's website. When the supplier in keen to maintain the attractiveness of its own direct sale channel in comparison to other PCWs, it will consequently increase the price charged on other sales channels, even if they did not increase their commission level. ${ }^{65}$

The reason this theory of harm is limited in its application, is that it is likely to apply where the supplier runs a significant volume of sales through its own upstream website; a sales channel which it is keen to protect, and the level of inter-brand competition which the

\footnotetext{
${ }^{65}$ The CMA considered such a possibility in its Report on the Private Motor Insurance Market. UK Competition and Markets Authority (CMA), Private motor insurance market investigation: Final report (CMA Report, September 2014) 8.46-8.54 <https://assets.digital.cabinetoffice.gov.uk/media/5421c2ade5274a1314000001/Final_report.pdf> accessed 22 Sep 2015.
} 
supplier faces, affecting the supplier's ability or incentive to decrease its product prices, is relatively low, enabling it to charge higher prices.

Absent these conditions, network effects are unlikely to materialise under narrow MFNs. Therefore, the practical manifestation of such effect is likely to be limited. Note, for instance, the UK Competition and Markets Authority's investigation into the Private Motor Insurance Market. The CMA noted that when a direct channel has been highly significant for the upstream supplier, that supplier would often not be listed on PCWs, making narrow MFN considerations irrelevant. ${ }^{66}$ It therefore concluded that narrow MFNs were unlikely to have a network effect impacting on competition between PCWs.

Similarly, in the Booking.com investigation, the agencies considered the hotels' incentive to grant Online Travel Agents (OTAs) lower room rates relative to that charged on the hotels' websites or through other OTAs. They concluded that the removal of wide parity used by all OTAs active on the market, the removal of availability parity and the use of narrow parity, would lead to a decrease in commission charged, a decrease in the rates for rooms and a shift to closed user group members' rates (CUG) which fall outside the scope of the narrow parity obligation. ${ }^{67}$ This conclusion emerged from consideration of the market characteristics. For instance, the fact that hotels' websites provide only for a small proportion of online sales and obtain most online reservations through OTAs. Also the fact that OTAs provide costeffective advertising and sale channels, which benefit hotels and reduce the cost risk to which they are subjected. ${ }^{68}$ In addition, relevant was the availability of loyalty programmes as a distinct channel not covered by MFNs. Overall, in such a market reality, hotels may be incentivised to offer lower prices through OTAs and undercut their own websites, thus eliminating risk of network effects or upward pressure on commissions.

It is worth noting that even when the market could give rise to network effects, they may nonetheless be countered by further narrowing of the parity clause. The agreement may, for instance, carve out certain groups of customers or offline sales. ${ }^{69}$ The Booking.com

\footnotetext{
${ }^{66} I d$, Point 8.51.

See for instance, the French Competition Authority decision, paras 305-309 <http://www.autoritedelaconcurrence.fr/pdf/avis/15d06.pdf > accessed 12 Nov 2015.

${ }^{68}$ Note for instance the costs associated with pay-per-click advertising and meta-search site costs and costs hotels may incur for direct customer acquisition.

${ }^{69}$ Furthermore, the absence of availability parity does allow a supplier to directly sell its stock, or in the case of hotels to sell its "last $\operatorname{room}(\mathrm{s}) "$.
} 
commitments included such mechanism, retaining the hotels' freedom to offer lower prices or better terms to those customers who register on their websites or purchase offline. Indeed, many hotels now include on their websites a statement informing users of the benefits of joining their loyalty programmes. Such approach disrupts potential network effects and reintroduces horizontal price competition. In addition to open price competition between OTAs, noteworthy is the availability of differentiated pricing on OTAs, such as lastminute.com and hotels.com which offer 'top secret hotels' and 'secret prices'.

\section{Reduction in vertical competition}

The second theory of harm concerns the reduction in vertical competition between the webaggregator and the upstream supplier. Recall that, under a narrow MFN, the upstream supplier cannot sell at better terms than are available downstream. This restriction may raise concern when it significantly reduces the competitive pressure that the supplier can apply on the downstream market, thus resulting in higher prices.

In its Private Motor Insurance Market Investigation, the CMA explored this theory of harm by measuring the constraint which PMI providers' websites placed on PCWs. The CMA found that 'in general, attracting customers through PCWs was cheaper for PMI providers than direct customer acquisition. ${ }^{70}$ This led the CMA to conclude that PCWs had the overall effect of lowering costs for PMI providers.

The CMA further considered the price elasticity of demand exhibited through different sales channels. It found that customers' ability to 'compare directly the prices of different policies on PCWs was likely to be a major driver of inter-brand competition', adding that 'whilst narrow MFNs limited competition between the own website and the PCW, this was unlikely to have much of an impact on competition between brands. ${ }^{71}$ It concluded that the restriction on competition imposed by narrow MFNs was unlikely to be significant.

\footnotetext{
${ }^{70}$ UK Competition and Markets Authority (CMA), Private motor insurance market investigation: Final report (CMA Report, September 2014) $8.56 \quad$ https://assets.digital.cabinetoffice.gov.uk/media/5421c2ade5274a1314000001/Final_report.pdf $>$.

${ }^{71}$ Id, Points 8.62-8.63.
} 
As illustrated above, in the Booking.com investigation narrow parity was likely to incentivise hotels to offer cheaper room rates through PCWs rather than on their website. As put by the Italian Competition Agency:

The projections made by the Authority in relation to Booking's simulation model prove this argument. They show that hotels usually have incentives to offer lower commissions in an OTA compared to those offered on their website. $^{72}$

Again, as with the first theory of harm, one should bear in mind that, even when an effectsbased analysis reveals harm, such harm may be addressed by a further narrowing of the MFN, carving out groups of customers or sale channels in order to stimulate competition.

\section{Narrow Parity - Enforcement Highlights}

Overall, the more limited intrusion into the supplier's freedom to set its price and terms under narrow MFNs has been accepted in several jurisdictions as providing a satisfactory equilibrium, which promotes downstream investment in demand-enhancing features and information provisions without constituting too intrusive a restriction on competition.

The scrutiny of Booking.com's practice and commitments across Europe is illustrative. Commitments made by Booking.com to narrow the scope of its parity clauses were accepted initially by the French, Swedish and Italian competition agencies. ${ }^{73}$ Under these commitments, Booking.com agreed to abandon its wide MFNs (which established price, availability and booking conditions' parity with respect to other OTAs ${ }^{74}$ ) and replace them with a narrow MFN, establishing a direct linear link to govern price and term parity with each hotel's own direct website. Under these commitments, the hotels retain the freedom to determine the price offline and to offer discounts to select groups of customers (such as members of the hotel's loyalty scheme and former customers). In addition, hotels are no

\footnotetext{
${ }^{72}$ Mercato Dei Servizi Turistici-Prenotazioni Alberghiere On Line I779 (Italian NCA decision) para 59 $<$ http://www.agcm.it/concorrenza/concorrenzadelibere/open/41256297003874BD/660EE2E99780F7B5C1257E350039D1CD.html>.

${ }^{73}$ The authorities were appointed by the ECN to jointly lead the European national proceedings regarding MFNs. On the investigation, see: Edurne Navarro Varona and Aaron Hernandez Canales, 'Online Hotel Booking' (2015) CPI Antitrust Chronicle May 2015 (1).

${ }^{74}$ Booking.com, 'Booking.com Announces Support of New Commitments in Europe' (Booking.com, 21 April 2015) <http://news.booking.com/bookingcom-announces-support-of-new-commitments-in-europe/> accessed 16 Nov 2015.
} 
longer bound by availability parity, which previously limited their ability to offer more rooms through selected distribution channels. ${ }^{75}$ The investigating agencies considered the narrowing of the parity clauses to provide a successful balancing formula sufficient to resolve their concerns. ${ }^{76}$ The Swedish competition authority noted that the narrow MFN reduces the risk that hotels free-ride on investments made by Booking.com:

This in turn allows Booking.com to receive remuneration for its search and compare services so that the services can continue to be offered on the market to the benefit of consumers. ${ }^{77}$

The results of the analyses carried out by the Competition Authority support the conclusion that hotels will have incentives to offer lower room prices in exchange for lower commission rates. An important motivation for the hotels in this context will be the competition between hotels for room bookings. ${ }^{78}$

Similarly, the French Competition Agency noted that:

The final commitments made by Booking.com... re-introduce competition between OTAs, address the risk of foreclosure of competing OTAs and notably new entry OTAs and enable to respond to competition concerns even though similar undertakings have to date not been taken by other OTAs. Furthermore, contrary to allegations of certain contributors to the market test, the commitment relating to the partial removal of the price parity provision is not tantamount to maintaining wide de facto price parity provision. ${ }^{79}$

\footnotetext{
${ }^{75}$ The NCAs concluded that relevant market is the OTA only (therefore, OTAs are not competing with hotels and only form an alternative distribution channel that without availability parity obligation can be used and utilised at a hotel's discretion).

${ }^{76}$ Note, however, possible variations to MFNs which may raise other concerns - see, for instance, the UK Competition Appeal Tribunal ruling in Skyscanner Limited v Competition and Markets Authority Case No. 1226/2/12/14, 26 Sep 2014, [2014] CAT 16. The judgment annulled an earlier OFT decision which accepted commitments with respect to OTAs' freedom to offer discounts off the published room rate, to a defined group of customers, up to the level of commission charged by the OTAs. According to the commitment, the discounts offered by the OTAs will not be publicly available outside the defined customer group.

77 Swedish Competition Authority, Bookingdotcom Sverige AB and Booking.com (unofficial translation) (15 April 2015) Ref: 596/2013, Point 30.

${ }^{78} I d$, Point 46.

${ }^{79}$ French Competition Authority, Decision no 15-d-06 of 21 April 2015 on the practices implemented by Booking.com b.v., Booking.com France sas and Booking.com customer service France sas in the online hotel reservation sector (unofficial translation), Point 281.
} 
The agency held that, as Booking.com eliminated its wide parity clause and detached the link between its prices and prices on other PCWs, offline and on selected hotel channels, it reestablished the link between the commission level imposed by Booking.com and the volume in demand:

In fact, accommodations will have the possibility of offering more attractive prices and better availability to competing OTAs of Booking.com which offer lower commission rates, which would thus enable the latter to increase the volume of their reservations and thus increase their market share... The hotels may thus transfer any increases in the commission rates charged by Booking.com to the rate levels granted to the latter, without the obligation of also increasing the rates throughout the direct channel. Alternatively, the hotels may reduce the number of rooms made available on Booking.com in response to an increase in its commission rates. ${ }^{80}$

In line with the above, the Italian Competition Authority noted in its commitment decision that:

The removal of the hotels' obligation to offer to Booking rates and conditions that are equal or more favourable than those offered to competing OTAs, will give these platforms the opportunity to use the commissions as competitive leverage in order to obtain from partner hotels more favourable conditions to be offered to consumers. ${ }^{81}$

Further, in a press release it concluded that:

The commitments offered by Booking.com strike the right balance for consumers in France, Italy and Sweden, restoring competition while at the same time preserving user-friendly free search and comparison services and encouraging the burgeoning digital economy. ${ }^{82}$

\footnotetext{
${ }^{80} I d$, Points 283, 284.

${ }^{81} I d$, Point 49.

${ }^{82}$ Italian Competition Authority, Commitments Offered by Booking.Com: Closed the Investigation in Italy, France And Sweden (Italian Competition Authority Press Release, 21 April 2015)
} 
Booking.com has applied the commitments in all EU Member States. ${ }^{83}$ As of January 2016, the commitments were publically accepted or tacitly endorsed by 25 competition authorities across Europe. ${ }^{84}$ In contrast to that approach, however, the Bundeskartellamt took a harsher, albeit isolated line, declined to accept the commitments offered by Booking.com and issued a prohibition decision. ${ }^{85}$ The Bundeskartellamt opined that the Düsseldorf Higher Regional Court's holding in HRS supported a complete ban on MFNs. Accordingly, since in that case the Bundeskartellamt rejected an absolute, yet temporary, ban on MFNs, the less extensive commitments offered by Booking.com were deemed unacceptable. Andreas Mundt, President of the Bundeskartellamt, noted on this point that the divergent approach may be possible as the decision concerns the national German market. ${ }^{86}$

Since the Düsseldorf Higher Regional Court's holding in HRS served as the foundation of the Bundeskartellamt's decision to reject Booking.com's commitments, it is worthwhile to

<http://www.agcm.it/en/newsroom/press-releases/2207-i779-commitments-offeresd-by-bookingcom-closed-theinvestigation-in-italy-france-and-sweden.html> accessed 20 Sep 2015.

8383 Booking.com, 'Booking.com Announces Support of New Commitments in Europe' (Booking.com, 21 April 2015) <http://news.booking.com/bookingcom-announces-support-of-new-commitments-in-europe/> accessed 20 Sep 2015.

${ }^{84}$ The Dutch Authority for Consumer and Markets (ACM) announced its approval of the proposed panEuropean solution and refrained from launching its own investigation. See: ACM, ACM is positive about European solution for hotel booking website Booking.com (ACM Press Release, 21 April 2015) <https://www.acm.nl/en/publications/publication/14188/ACM-is-positive-about-European-solution-for-hotelbooking-website-Bookingcom/>; Similarly, see decision by the Danish Competition Authority 〈http://www.kfst.dk/Indhold-KFST/Nyheder/Pressemeddelelser/2015/20150827-Konkurrence-og-

Forbrugerstyrelsenindstiller-undersoegelse-afbookingportaler?tc=B6F3E10C347948C7B9A4993A9A43DB4E $>$; Also note decision by the UK CMA to drop the investigation into Booking.com: CMA, CMA closes hotel online booking investigation (CMA Press Release, 16 September 15) <https://www.gov.uk/government/news/cma-closes-hotel-online-booking-investigation>; Hellenic Competition Commission (Greece), HCC decides not to proceed with a formal investigation into BOOKING \& EXPEDIA's cooperation agreements with hotel businesses in Greece (Hellenic Competition $\begin{array}{llllll}\text { Commission } & \text { Press } & \text { Release, } & 22 & \text { September } & \text { 2015) }\end{array}$ http://www.epant.gr/news_details.php?Lang=en\&id=89\&nid=786>; The Irish Competition and Consumer Protection Commission agreed the same commitments as the French, Italian and Swedish authorities: See Competition and Consumer Protection Commission (Ireland), Commission secures 5-year commitments from Booking.com (Press Release, 6 October 2015) <http://www.ccpc.ie/news/2015-10-06-commission-secures-5year-commitments-bookingcom>; Competition Commission (Switzerland), COMCO prohibits anticompetitive contract clauses by hotel booking platforms (Press Release, 6 November 2015) <https://www.news.admin.ch/message/index.html?lang=en\&msg-id=59358>; Also, see generally: Matthew Newman and Lewis Crofts 'Booking.com defends pricing clauses as German decision looms' (mlex market insight, 3 December 2015)

${ }^{85}$ Bundeskartellamt, Narrow 'best price' clauses of Booking also anticompetitive (Bundeskartellamt Press Release, 23 December 2015)

<http://www.bundeskartellamt.de/SharedDocs/Meldung/EN/Pressemitteilungen/2015/23_12_2015_Booking.co m.html> accessed 3 Jan 2016.

${ }^{86}$ MLex, 8 May 2015. 
appraise the ruling more carefully and consider the extent to which it supports a complete ban on MFNs.

In its judgment, the Düsseldorf Higher Regional Court focused on the effects of the wide MFNs used by HRS, the way they deprived customers of the opportunity to obtain a more advantageous room price for the same hotel room on other sales channels, and their adverse effect on entry, commissions and price. ${ }^{87}$ Importantly, however, the Court's judgment made no comment regarding narrow MFNs, nor conducted substantive analysis of their effects. The Court accepted the Bundeskartellamt's rejection of HRS' commitment to remove the wide parity clause for a five-year period, raising doubts as to the temporary nature of the commitment ${ }^{88}$ and HRS' possible recalcitrance. ${ }^{89}$ The Bundeskartellamt considered that only a prohibition order would suffice to ensure that the MFNs were eliminated and to guarantee legal certainty for HRS' contracting partners. On appeal, the Court endorsed the decision and held that the precedent-setting effect of an infringement decision was extremely important in this case $:^{90}$

Precisely because the antitrust evaluation of most favoured nation clauses has so far not been clarified in sectors of the internet economy, and anti-trust proceedings for using best price clauses have been initiated against other major providers of hotel portal services by the Federal Cartel Office and in other European countries (such as France, Austria, Switzerland, Sweden, Ireland and Italy), the finding of an infringement of antitrust law by the Federal Cartel Office acquires particular significance. ${ }^{91}$

The Court further noted that a commitment decision would not have had this binding effect and could not therefore have provided a valuable statement on the lawfulness or unlawfulness

\footnotetext{
${ }^{87}$ Kart 1/14 (V) (9 January 2015) Higher Regional Court of Düsseldorf, VI.

${ }^{88} I d$, Point 265, 'The Decision Division rejects the time-limited commitments recently offered by HRS because they are not suited to conclude the proceedings with findings of the violation and with the effective termination of the infringement within the meaning of section 32 (1) and (2) GWB. The time-limited commitments offered by HRS would not remove the sincere concerns of the Decision Division.'

${ }^{89} I d$, 'It is not even decisive here that, in the context of the ongoing administrative proceedings, HRS has not completely complied with the commitments that it made to forego the enforcement of the MFN clauses and that this gives rise to doubt as to reliability of HRS with regard to the commitments offered.'

${ }^{90}$ Id, Point 187.

${ }^{91} I d$, Point 188 (unofficial translation).
} 
of the conduct at issue. ${ }^{92}$ Importantly, the Court's judgment focused, from start to finish, on the wide parity clause used by HRS and the proposal to remove it for a period of 5 years. As the decision under review focused solely on wide parity, the Court did not engage in an analysis of likely effects of narrow MFNs; and did not consider a proposal for an alternative narrow parity on a permanent basis. Its ruling was driven by the facts of the case and the need for clarity as to the legality of wide MFNs.

With that in mind, the Bundeskartellamt's reading of the judgment seems overly wide. Its conclusions regarding narrow parity do not flow naturally from the Court's judgment, nor do they reflect its substantive analysis. In other words, a ban on wide MFNs and a refusal to accept commitments which provide only temporary relief from wide MFN do not provide a firm analytical foundation upon which to base a ban on narrow MFNs. Beyond this, the conclusions seem to ignore the risk of free-riding which narrow parity addresses and the danger that an absolute ban would diminish investment downstream and increase inefficiencies. ${ }^{93}$ Recall, in particular, that that downstream investment by OTAs may play a crucial part for small and medium size enterprises' entry and expansion.

From a wide European perspective, concerning is the inconsistency between the Bundeskartellamt's position, and the approach of other national competition agencies which endorsed Booking.com's commitments. This inconsistency highlights the need for effective coordination and for greater analytical alignment between national competition agencies (NCAs). ${ }^{94}$ As noted by Commissioner Vestager, the Booking.com cases have been a "learning experience" and a "very good example" of how greater coordination is needed. ${ }^{95}$

\footnotetext{
${ }^{92}$ Id, Point 188.

${ }^{93}$ For instance, free-riding is likely to reduce conversion rate, increase costs for OTAs and subsequently the commission they charge.

${ }^{94}$ European Commission, Cooperation within the Network of Competition Authorities (Commission Notice, Official Journal C 101, 27 April 2004), 43-53.

95 Matthew Newman 'Vestager says Booking.com case shows EU should intervene earlier in new markets' ( $m$ lex market insight, 15 June 2015). Also note, the speech by Directorate-General Laitenberger, delivered on 21 September 2015 at the Competition and Consumer Day, Luxembourg Presidency event: "Businesses and consumers expect legal certainty, predictability, and a uniform application of the law. Let us not forget that there is only one EU competition law and its application should not vary from one authority to the next." <http://ec.europa.eu/competition/speeches/text/sp2016_01_en.pdf>; Also note comments by Bruno Lasserre, President of the French Competition Authority, who noted the need "to have maybe a broader coordination to be sure that everybody in Europe, the 28 member states, are all in the same line" (Matthew Newman and Flavia Fortes 'National regulators should approach EU commission promptly when conclusions diverge' (mlex market insight, 29 September 2015).
} 
The Commissioner announced the establishment of a joint working group which includes the European Commission and NCAs, and will monitor the effects of accepted remedies. ${ }^{96}$

\section{The Adequate Level of Intervention}

The balancing exercise between the competitive promise of online MFNs, on the one hand, and their anti-competitive effects, on the other, is not a simple one. As illustrated above, the analysis of both wide and narrow parity is context-dependant. These provisions may include a number of restrictions, not all price related, and they differ in scope and effect.

Overall, the distinction between wide and narrow parity reflects two opposing ends of the spectrum. While the use of wide MFNs has largely been viewed as overly restrictive of competition, the use of narrow MFNs provides for a more balanced effect.

As illustrated above, narrow MFNs facilitate investment by PCWs in services and demandenhancing features, while simultaneously protecting them from direct free-riding by the supplier. The narrow provision does not limit competition between PCWs on price and service, and opens the door for differentiated pricing to the benefit of customers. The presence of the intermediary - the PWC - offers welfare-enhancing services for customers, as well as efficiencies and risk mitigation for suppliers. In addition, it facilitates the entry of new suppliers, and enhances both inter- and intra-brand competition.

On a case-by-case analysis, the competition agency would explore the market dynamics and the possible effects generated by narrow MFNs and PCWs. From a legal perspective, that analysis may be conducted using three distinct analytical approaches.

First, under Article 101(1) TFEU, an analysis of the market characteristics and the dynamics of competition would explore the likely competitive effects of narrow MFNs. ${ }^{97}$ Such

\footnotetext{
${ }^{96}$ Lewis Crofts 'Booking.com, Expedia, face Europe-wide monitoring of online-booking remedies' (mlex market insight, 8 December 2015).

${ }^{97}$ This is so, as by their nature, narrow parity clauses do not constitutes a restriction of competition by object. See for instance: Case C-67/13 P Groupement des cartes bancaires v European Commission, para 58, where the Court of Justice held that: "The concept of restriction of competition "by object" can be applied only to certain types of coordination between undertakings which reveal a sufficient degree of harm to competition ...'.
} 
assessment would take account of the likely impact these narrow parity clauses may have on inter- and intra-brand, actual or potential competition.

Second, under Article 101(3) TFEU, such provisions may be permitted even when they are found to have the effect of restricting competition, provided that those restrictions are limited in nature and satisfy the exemption conditions. ${ }^{98}$ The onus will be on the parties to establish: (a) the presence of efficiency gains through the use of the intermediate online platform; (b) that the restrictions put forward by the narrow MFN are indispensable to attain these efficiencies; (c) that the efficiency gains are passed to consumers; and (d) that competition in respect of a substantial part of the products in question in not eliminated. ${ }^{99}$

A third analytical approach may utilise the ancillary restraint doctrine developed in case law. Accordingly, narrow parity may be viewed as ancillary to the agreement between the PCW and the supplier: a restriction without which the benefits provided by the online platform would not materialise (due to the fact, for example, that investment downstream would be undermined). ${ }^{100}$ The assessment of ancillary restraints is limited to determining whether, in the context of the main non-restrictive activity - i.e. the promotion of the supplier's product or service - a particular restriction is necessary for the implementation of that activity and proportionate to it. ${ }^{101}$ Accordingly, a restriction imposed by a narrow MFN will not be caught by Article 101 TFEU when it is limited to what is necessary to ensure the delivery of the services offered by the web-aggregator to the supplier.

As the nature of an effects-based analysis is its context-dependency, no absolute statement can be made as to the legality of narrow MFNs. Still, with this caveat in mind, recent investigations and commitment decisions suggest that the restrictions afforded by narrow parity facilitate competition dynamics and are welfare-enhancing.

\footnotetext{
${ }^{98}$ The assessment under Article 101(3) TFEU requires prior determination of the restrictive nature and impact of the clause. See: European Commission, Guidelines on the application of Article 101(3) TFEU (Communication from the Commission, OJ C 101, 27 April 2004) 97-118.

${ }_{99}$ Also note the possible application of Block Exemptions.

100 Case 42/84 Remia BV and Nv Verenigde Bedrijven Nutricia v Commission [1985] ECR 2545, [1987] 1 CMLR 1 (ECJ); Case T-112/99 Metropole Television (M6) and others v Commission [2001] ECR II-2459, [2001] 5 CMLR 33; Case C-250/92 Gøttrup-Klim v Dansk Landbrugs Grovvareselskab AmbA [1994] ECR I5641, [1996] 4 CMLR 191, para 45.

${ }^{101}$ European Commission, Guidelines on the application of Article 101(3) TFEU (Communication from the Commission, OJ C 101, 27 April 2004) paras 30-31.
} 


\section{State Intervention}

Having discussed the adequate scope of competition law intervention, one should be mindful of other enforcement tools at the disposal of the State. A state may favour other enforcement or regulatory vehicles over competition law when dealing with distinct industries or markets. ${ }^{102}$ Political, social, industrial and economic interests - which are external to competition analysis - may play a role in some industries, leading to varying levels of intervention. While such an approach may well have limited grounding in competition analysis, it may reflect a legitimate political or social agenda.

Importantly, state intervention through legislation or regulation should not be confused with competition law analysis. In fact, it is often the case that 'external' intervention is called for exactly in instances in which the competition analysis reveals no harm and yet the State is concerned with wider consequences. ${ }^{103}$ Such may be the case, for instance, when competition law intervention is not triggered because overall consumer welfare is enhanced, yet the State is concerned with the distribution of welfare, an imbalance in bargaining power or other social goals which trigger non-competition intervention.

An illuminating example in the context of parity clauses was provided by the French legislator's ban on all MFNs in the French hotel sector. ${ }^{104}$ In July 2015, the French National Assembly approved a ban on all rate parity clauses in contracts between PCWs and hotels. The legislation secures the freedom of hotels to set lower prices both online and offline, and thus altered the position endorsed by the French Competition Agency in its commitment decision, which viewed narrow online MFNs as permissible following its competition law analysis. ${ }^{105}$ This prohibition followed a campaign by the European Trade Association of

\footnotetext{
102 A. Ezrachi, 'Sponge' (2015) The University of Oxford Centre for Competition Law and Policy Working Paper CCLP (L) 42, Oxford Legal Studies Research Paper No. 16/2015 <http://papers.ssrn.com/sol3/papers.cfm?abstract_id=2572028> accessed 16 Nov 2015.

$10 \overline{3}$ Alternatively, it may reflect an attempt by the state to put a clear and instant restriction in place. See for example the state of Michigan ban on MFN clauses, which led to the dismissal of the DOJ case against BCBSM. See fn 61 above.

${ }^{104}$ Vote by the French National Assembly on the 'Law Macron' (9 July 2015).

105 Also note a ruling by the Paris Commercial Tribunal in a claim launched by the State against Expedia. The Court reviewed MFNs used by Expedia between 2006 and 2011 and held that they reflected a significant imbalance between the rights and obligations of the parties and were objectionable under the French Commercial Code. See: Ministry of Economy and Industry and Digital / Expedia Inc. and others - and the Ministry of Economy and Industry and digital / Hotel.com LP (7 May 2015) Commercial Court of Paris, 13th Chamber <http://www.legalis.net/spip.php?page=jurisprudence-decision\&id_article=4629> accessed 2015.
} 
Hotels (HOTREC), which objected to the commitments offered by Booking.com and lobbied for the absolute prohibition of MFNs.

The prohibition of all MFNs in the French hotel sector was welcomed by Roland Heguy, President of HOTREC's French member association UMIH:

It is a real revolution that is underway for the French hotel industry and for our customers. After the decision of the Competition Authority, this vote will contribute to the establishment of a renovated contractual framework to restore conditions of a commercial relationship based on trust between hotels and booking sites in the interest of consumer. ${ }^{106}$

Similarly, Susanne Kraus-Winkler, President of HOTREC, welcomed the change:

The European hotel industry sees this decision as a key milestone to restore complete entrepreneurial freedom for hoteliers all across Europe. After Germany which banned parity clauses in a competition case, followed by a Court judgment, France is opening a potential new way forward through the legislative process. ${ }^{107}$

While the legislator has the power to advance and promote a range of policies, not all consistent with competition law, in this particular legislation, it seemed to engage with the aim of remedying competition on the market and favouring its own balancing point over that endorsed by the competition agency. On the other hand, it is worth noting that the ban has been applied selectively, only to the hotel sector and not to other industries. Such selective application suggests a limited competition rationale and the promotion of narrow interests, by selected stockholders. ${ }^{108}$

So, what are the possible benefits of the absolute ban? Most striking is the effect on the bargaining position of OTAs in their linear agreements with each hotel. The ban provides

\footnotetext{
${ }^{106}$ Hotrec, 'France Forbids Rate Parity Clauses by Law Another Crucial Step for Hotels in Europe to Regain Control Over Their Offer' (Hotrec, 9 July 2015) < http://www.hotrec.eu/newsroom/press-releases-1714/franceforbids-rate-parity-clauses-by-law-another-crucial-step-for-hotels-in-europe-to-regain-control-over-theiroffer.aspx > accessed 20 Sep 2015. ${ }^{107} I d$.

${ }^{108}$ From a competition perspective, it is important to note that, at present, narrow MFNs in industries outside the hotel sector in France remain permissible subject to an effects based analyses.
} 
hotels with the freedom to undercut offers made by online platforms and subsequently is likely to improve their stance in future negotiations with OTAs.

And what may be the competitive costs? These could possibly be found in the French Competition Agency's analysis which permitted narrow MFNs. The risk of free-riding may lead to subsequent reduced investment downstream, to reduced conversion rates and an increase in costs for information and search. Further, the ban may increase barriers to entry and expansion for small- and medium-size hotels. These entities are likely to have difficulties coping with the risks and costs associated with direct advertising and sales. If indeed so, the upstream market may witness an increase in the market power of larger business which would benefit from reduced competitive pressure. In such case, the changing market dynamics are likely to be welfare-reducing.

\section{Concluding remarks}

Parity clauses provide us with an illustration of the complex balancing exercises that competition enforcers engage in. On the one hand, these clauses enable welfare-enhancing investment and innovation downstream, which benefit customers and suppliers. On the other, they may lead to a restriction of competition through excessive intermediation and price uniformity and they may also limit low cost entry.

Two distinguishable strands of parity - narrow and wide MFNs - lead to different effects. As illustrated, unlike wide parity, narrow parity has been largely found to provide an adequate balancing formula - limiting externalities and facilitating investment downstream.

Naturally, the analysis is fact-intensive and dependent on the market context. Different market realities and different agreements may yield ranging effects. Importantly, however, a blank refusal to consider the role played by narrow MFNs may cut too deep into the competitive process and harm both suppliers and customers.

A detailed market-oriented analysis has to weigh the risks of externalities and free-riding and the way these may affect the dynamics of competition and investment. It has to consider the benefits afforded by PCWs and the role they play as intermediaries - facilitating entry and competition. In that respect, the imposition of an absolute ban as put forward by French legislation is worrying. To the extent that it aimed to protect consumers and competition, it 
26 January 2016

might have indeed missed its target. After all, as unfortunate as it may be, externalities are not costless, even when endorsed by the State. 